Bernard Hamilton, Janet Hamilton (Nottingham)

\title{
St. Symeon the NeW Theologian AND Western Dissident Movements
}

The execution on Holy Innocents day 1022 of a group of canons of the cathedral of the Holy Cross, Orleans, together with some of their followers, convicted of heresy at a synod convoked by Robert the Pious, was widely reported. M.R.-H. Bautier has brilliantly explained the political context of the trial and has also explained the priority of the two Fleury sources ${ }^{1}$. Abbot Gauzlin of Fleury, together with a group of senior brethren, had been present at the Synod of Orleans and, soon after the trial, the Catalan monk John, who was staying at Fleury, wrote about it to Oliba, abbot of Ripoll. He describes the heretics as radically anti-sacramental; they denied the saving grace of baptism, the validity of the Mass and the efficacy of sacramental confession; and they deprecated marriage ${ }^{2}$. Andrew of Fleury, who may have been present at the Synod in 1022, wrote a Life of abbot Gauzlin in c. 1042, in which he tells us that the heretics professed belief in the Holy Trinity and in the incarnation of Christ, but rejected the sacraments. They denied that the Holy Spirit was conferred at baptism; they saw no value in the laying-on of hands or in sacramental confession; they held that bishops could not validly ordain priests because they did not have the power to confer the Holy Spirit (which implied, of course, that priests could not celebrate valid Masses). They considered that blessing marriages was pointless and argued that a man should marry whom he liked and how he liked ${ }^{3}$.

\footnotetext{
1 R-H. BAUtier, L'hérésie d'Orléans et le mouvement intellectuel au début du XI siècle. Documents et hypothèses, [in:] Actes du $95^{e}$ Congrès national des sociétés savantes, Section philologique et historique, vol. I, Enseignement et vie intellectuelle (IX ${ }^{e}-X V I^{e}$ siècle), Paris 1975, p. 63-88.

2 John adds a cibis etiam quos Deus creavit, hoc est a carne et adipe, tanquam ab inmundiciis, se abstinebant. $\mathrm{He}$ is the only source to make this allegation. This practice is not in itself heretical. Austere monks in East and West throughout the Middle Ages refused to eat meat - Johannes monachus ad Olibam, [in:] André de Fleury, Vie de Gauzlin, abbé de Fleury, ed. et trans. R-H. de Bautier and G. Labory, Paris 1969 (cetera: ANDRÉ DE FleUry), p. 180-182 [= SHM, 2].

3 Andrew added that the heretics did not believe that the Church existed, and also claimed to have a mother similar to the Mother of God, at least that is what we take to be the meaning of the following; Non credebant Aecclesiam esse, nec per id quod continet dici posse id quod continetur... Filii Dei genetricem se habere similem et per omnia jactabant, cum nec similis visa sit nec habere sequentem - ANDRÉ DE FLEURY, col. 56, p. 96-98).
} 
Bautier tends to play down the value of the fullest account of this heresy, which records the part played in the trial by Aréfast, because the version of it which we now have was only entered into the cartulary of St. Père de Chartres by the monk Paul in c. $1080^{4}$. It relates how Aréfast, a Norman aristocrat, whose clerk Heribert had been won over by the heretics of Orleans, infiltrated their movement by posing as a potential convert. He informed Richard II of Normandy of his intention, and the duke alerted king Robert, who summoned the synod of Orleans at which Aréfast gave evidence and the heretics were condemned. This account, while in agreement with the sources written at Fleury that the heretics denied the efficacy of baptism and of the Mass, also reports that they asserted that the material universe was eternal and denied the incarnation. Aréfast asked them what he must do to attain salvation, since they held that the normal means of grace were unavailing, and was told:

We will open the gate of salvation to you, and having entered in through the laying on of our hands, you will be cleansed from all your sins and filled with the gift of the Holy Spirit Who will teach you the deep and true religion of all the Scriptures without any reservation. Then you will be refreshed and inwardly satisfied by being fed with heavenly food and you will often, with us, see visions of angels...

Aréfast was the uncle of Richard II of Normandy and a generous benefactor of St. Père de Chartres, where he became a monk before $1029^{6}$. The date of his death is not known but it is unlikely that the archivist Paul could have known him ${ }^{7}$. Nevertheless, it seems likely that Paul copied an earlier text which derived directly from Aréfast, because some version of this account seems to have been known to Rodulphus Glaber, the chronicler of Cluny, who wrote soon after 1046. His knowledge of the trial almost certainly came from Odolricus, bishop of Orleans ${ }^{8}$. Glaber

4 Monasterii Sancti Petri Carnotensis Codex Diplomaticus, pars I, Quae dicitur Vetus Aganon, col. 111, [in:] Collection des documents inédits sur l'histoire de France, Collection des Cartulaires de France, ed. M. GuÉRARD, vol. I, Paris 1840 (cetera: Monasterii Sancti Petri), p. 109-115; R.-H. BAUTIER, op. cit., p. 67-69.

5 Pandemus tibi salutis hostium, quo ingressus, per impositionem videlicet manuum nostrarum, ab omni peccati labe mundaberis, atque Sancti Spiritus dono repleberis, qui scripturarum omnium profunditatem ac veram divinitatem absque scrupulo, te docebit. Deinde coelesti cibo pastus, interna societate recreatus, videbis persepe nobiscum visiones angelicas... - Monasterii Sancti Petri, p. 111.

6 His charter giving extensive property to St. Père is recorded by Paul of Chartres - Monasterii Sancti Petri, p. 108-109.

7 Aréfast was the brother of Gunnor, who married Richard I of Normandy in c. 980 and died in 1031. Aréfast is last mentioned in a document of 1033 (Collection des documents..., p. CCLXXV, an. 2). Paul of Chartres, archivist in 1080, is unlikely to have been professed before c. 1050.

8 Glaber attributes errors to the heretics which are different from those given in other sources: that the doctrine of the Trinity cannot be proved from the Old and New Testaments; that sins of the flesh do not attract divine punishment; and that good works are irrelevant to salvation - Rodulfi Glabri Historiarum Libri Quinque, III, 8, 26-31, [in:] Rodulfus Glaber, Opera, ed. J. France, N. Bulst, P. Reynolds, Oxford 1989 (cetera: Rodulfus Glaber), p. 138-150 [= OMT]. Glaber met bishop 
gives a condensed account of how a Norman infiltrated the heretical cell, and, like the Aréfast document, accuses the canons, among other things, of believing in the eternity of the world ${ }^{9}$. Adhémar of Chabannes, writing in c. 1028, calls the heretics of Orleans Manichees and links them to other outbreaks of heresy in Aquitaine, but says nothing about their beliefs except that they denied Christ secretly and practised abominable rites clandestinely. Nevertheless he may be drawing on the Aréfast tradition, for he ascribes the gullibility of the learned canons to their eating a magic powder made from the flesh of dead children, an explanation found also in the Aréfast report ${ }^{10}$.

According to the Fleury sources the canons of Orleans were condemned because they denied the efficacy of the sacraments of the Church as a means of salvation. These accounts must be true, for had the canons been convicted of the more colourful errors attributed to them in the Aréfast report and the related sources, these would surely have been highlighted by the Fleury writers. Bautier claims that there is no need to seek an explanation for the canons' heterodox views about the sacraments outside the confines of northern France ${ }^{11}$. There was a good deal of speculation among learned clergy there in the early eleventh century about such matters, and this is reflected, for example, in the correspondence of Fulbert of Chartres ${ }^{12}$.

Odolricus (d. 1035) some time after his return from Constantinople and Jerusalem in the reign of Constantine VIII (1025-1028) - Rodulfus Glaber, IV, 6, 19, p. 202.

9 Celum pariter ac terram, ut conspiciuntur, absque auctore inicii semper extitisse asserebant - Rodulfus GLABER, III, 8, 27, p. 142; Paul of Chartres: Quibus [canonicis] praesul respondit: „Antequam quicquam fieret per naturam, non creditis per Filium, Deum patrem fecisse omnia ex nichilo?” Cui alienati a fide dixerunt: „Ista illis narrare potes, qui terrena sapiunt atque credunt ficta carnalium hominum, scripta in membranulis animalium; nobis autem qui legem scriptam habemus in interiori homine a Spiritu Sancto, et nichil aliud sapimus, nisi quod a Deo omnium conditore, didicimus, incassum superflua et a Divinitatis devia profers" - Monasterii Sancti Petri, p. 114. ${ }_{10}$ Paul of Chartres relates that the heretics indulged in sexual orgies and cremated the babies conceived at them and that they used the powder to make counterfeit eucharistic hosts which, if eaten, bound the recipients to their sect (Monasterii Sancti Petri, p. 112). As Dom Bouquet noted in his edition of this text, this calumny had also been circulated about the early Christians (as Justin Martyr reports) - Gesta Synodi Aurelianensis, ed. M. BouQuet et al., [in:] Recueil des historiens des Gaules et de la France, vol. X, Paris 1760 [repr. 1874], p. 538, an. (a). Adhémar de Chabannes says more succinctly: [Haeretici] decepti a quodam rustico, qui... pulverem ex mortuis pueris secum ferebat, de quo si quem posset communicare, mox Manichaeum faciebat - AdhÉmar, Chronique, col. 59, ed. J. CHAVANON, Paris 1897 (cetera: AdHÉmAR), p. 184-185. This source is critically examined by R. LANDES, Relics, Apocalypse and the deceits of history: Adhémar of Chabannes, 989-1034, Cambridge Mass. 1995, [= HHS, 117]. Most scholars have regarded the passage about orgies in Paul of Chartres' narrative as an interpolation, but we suggest that it might be an authentic part of Aréfast's testimony.

11 R.-H. Bautier, op. cit., p. 77-88.

12 Fulbert of Chartres, Epistolae, V, col. 106-204, [in:] PL, CXLI. This letter, written in 1007, is addressed to Adeodatus, who, Bautier suggests, might be Theodatus, cantor of Orleans, who appears to have been the first leader of the heretical group. He died in 1018 and bishop Odolricus ordered his body to be exhumed and removed from consecrated ground - ADHÉMAR, col. 59, p. 185. This identification remains uncertain. 
Yet although it seems likely that the Orleans group did hold some unorthodox views arising from intellectual speculation, they were not simply a group of academic theologians with doubts about their faith. It is clear from the Aréfast document that they were members of a religious movement who believed that they had a true understanding of the Christian faith because they had been enlightened by the Holy Spirit. Many of the claims they made find a close parallel in the teaching of their Byzantine contemporary, St. Symeon the New Theologian.

He was born in 949 and trained in the spiritual life by Symeon Eulabes, a monk of Studios in Constantinople, where the younger Symeon was himself professed. In 980 Symeon the New Theologian was ordained priest and made abbot of St. Mamas at Constantinople. He later came into conflict with the hierarchy for promoting the cult of his spiritual father, St. Symeon Eulabes, and was exiled to Bithynia in 1009. Although reconciled to the patriarch two years later, Symeon refused to return to live in the capital, but founded the monastery of St. Marina in Bithynia, of which he became abbot, and where he died on 18 March 1022. His disciple and executor, the monk Nicetas Stethatus, preserved his voluminous writings, and wrote Symeon's Life. Symeon was canonized by the patriarch Michael Cerularius (1043-1058) ${ }^{13}$.

St. Symeon stood in the tradition of Byzantine mystical theology which later became known as Hesychasm, and was its most eminent representative in the central Middle Ages. His aim was to train men in the life of Christian perfection, whose end was théosis, which has been described as the participation of the Christian in the divine and uncreated energies of God $^{14}$. The essential element in this training is submission to a spiritual father whom the candidate chooses through the guidance of the Holy Spirit ${ }^{15}$. The spiritual father prepares his pupil to receive baptism in the Holy Spirit, which is not characterized by any outward ceremony but by repentance of one's sins and voluntary acceptance of the Christian revelation ${ }^{16}$. Such teaching might easily lend itself to a devaluation of sacramental baptism, though St. Symeon's own views about that were completely orthodox ${ }^{17}$.

\footnotetext{
${ }^{13}$ Un grand mystique byzantine. Vie de Syméon le Nouveau Theologien (949-1022) par Nicetas Stéthatos, ed. et trans. I. Hausherr, G. Horn, Rome 1928 [OC, 12].

14 J.M. Hussey, The Orthodox Church in the Byzantine Empire, Oxford 1985, p. 357.

15 Syméon le Nouveau Théologien, Catéchèse XX, 11, 22-62, [in:] idem, Catéchèses, ed. B. KrivoChérne, trans. S. PARAmelle, vol. II, Paris 1964 [= SC, 104], p. 335-336.

16 Syméon le Nouveau Théologien, Traité X, 11, 114-118 (the grace of tears), 425-448 [in:] IDEM, Traités theologiques et éthiques, ed. et trans. J. Darrouzès, vol. II, Paris 1967 [= SC, 129] (cetera: SYMÉON, Traité X), p. 266-268, 290-292.

17 Syméon, Traité X, 11, 323-369, p. 282-286; B. Krivochéine, In the light of Christ. St. Symeon the New Theologian (949-1022): Life - Spirituality - Doctrine, trans. A.P. Gythiel, Crestwood-New York 1986, p. 141-148.
} 
The spiritual father was not necessarily a priest, nevertheless because he had attained enlightenment he was able to bind and to loose $\sin s^{18}$. Symeon had a very high view of the Eucharist which he considered an essential part of the Christian life. He does not suggest that it could be performed by anyone except a priest, or that unworthy priests were not able to celebrate valid Masses, but he taught that the grace of the sacrament was entirely dependent on the conscious disposition of the communicant. Those who were enlightened ate the flesh of God, whereas Christ withdrew his presence from the elements received by those who approached him unworthily ${ }^{19}$.

Symeon's teaching emphasized the importance of the holy man in the Christian life, and the Church hierarchy was seen as subordinate to that ${ }^{20}$. Symeon also taught that understanding the Scriptures was not an intellectual exercise, but a gift of the Holy Spirit:

So from the time that God lives and works in us... that is when we consciously contemplate what the coffer, that is to say the Holy Scriptures, contains by way of hidden and divine mysteries. Otherwise it is impossible - let no-one deceive himself about this - to watch the coffer of knowledge open itself and to enjoy the good things which it holds... ${ }^{21}$

Symeon was not writing simply for a monastic audience, but taught that the life of perfection was available to all Christian people ${ }^{22}$.

His teaching about the spiritual life corresponds quite closely to the claim made by the canons of Orleans to Aréfast: We will open the gates of salvation to you... you will be cleansed from all your sins and filled with the gift of the Holy Spirit who will teach you the deep and true religion of all the Scriptures... There is no evidence that St. Symeon's followers used a ceremony of the laying-on of hands to confer the second baptism and Bautier has questioned the authenticity of Paul of Chartres' assertion that the canons of Orleans did so, because Andrew of Fleury states specifically that they rejected this practice ${ }^{23}$. The laying-on of hands in spiritual baptism was a characteristic of Byzantine Bogomil (and later of Cathar) initiation, and because Adhémar of Chabannes described the heretics of Orleans as Manichees some scholars have argued that they were

\footnotetext{
18 This is discussed by B. KrIvochérne using the evidence of St. Symeon's letters (op. cit., p. 125-140).

19 Syméon le Nouveau Théologien, Hymne XXVI, [in:] idem, Hymnes, ed. J. Koder, trans. L. NeyRAND, vol. II, Paris 1971 [= SC, 174], p. 268-276; B. KrIVochÉINE, op. cit., p. 103-123.

20 J.M. HusSEY, op. cit., p. 365.

21 Syméon le Nouveau Théologien, Catéchèse XXIV, 11, 54-69, [in:] IDEm, Catéchèses..., vol. III, Paris 1965 [= SC, 113], p. 38-39.

22 See his final hymn LVIII, [in:] Hymnes..., vol. III, Paris 1973 [= SC, 196], p. 279-309.

${ }^{23}$ Pro nihilo computabant impositionem manuum - ANDrÉ De Fleury, col. 56, p. 98. This may simply mean that they rejected the sacrament of confirmation. They might have introduced the laying-on of hands for conferring spiritual baptism because of the Apostolic example of Acts 8, 17.
} 
dualists $^{24}$. But there is no convincing evidence of dualist belief in the opinions ascribed to them.

There is a striking similarity between the views of St. Symeon and those of the canons of Orleans as reported by Rodulphus Glaber, about the futility of trying to prove the doctrine of the Trinity from Holy Scripture. The canons' said that whatever the sacred authority of the Old and New Testaments taught about the Holy and Undivided Trinity, strengthened by known signs and wonders and by ancient witnesses, was fanciful. St. Symeon wrote: No-one, indeed, can conceive or express fittingly anything which relates to the Holy Trinity merely on the basis of reading the Scriptures. Basil Krivochéine comments on this passage: Only the grace of the Holy Trinity can reveal the Trinity ${ }^{25}$. Aréfast's report that the canons rejected the incarnation of Christ, if true, may be based on a similar assumption; St. Symeon taught that it was central to the Christian life to experience Christ as he is; and B. Krivochéine glosses this: To know Christ on the basis of Scripture only is practically impossible if one is not able to see $\mathrm{Him}^{26}$. The canons of Orleans may therefore have accepted the incarnation, as Andrew of Fleury said they did, on the basis of their own religious experience, but have rejected scriptural proofs of it.

Although St. Symeon's teaching was accepted as orthodox by the Byzantine church, it remained true, as Michael Angold has pointed out, that the dangers of heresy... were inherent in the mystical tradition of Byzantium ${ }^{27}$. It was a temptation to enthusiasts working in that tradition to reject the hierarchical church and its sacraments and to depend solely on the illumination granted by the Holy Spirit to those who had received the second baptism. It was also easy for the enemies of such men

${ }^{24}$ The Bogomil rite of spiritual initiation is described by Euthymius Zigabenus in his treatise Against the Bogomils, col. 16, [in:] Christian Dualist Heresies in the Byzantine World, c. 650 - c. 1450, trans. J. HAMilton, B. Hamilton, Manchester 1998, p. 189-190; the Cathar form of this rite is contained in the Cathar ritual - Rituel cathare, ed. C. Thouzellier, Paris 1976 [= SC, 236]. In the first edition of his Medieval Heresy: Popular movements from Bogomil to Hus (London 1977) Malcolm LAMBERT argued that there was almost certainly some Bogomil influence at work among the heretics of Orleans, although that may not have accounted for all their unorthodox beliefs, p. 24-36, 343-348; but in his second edition of 1992 he states that he has come to view the Orleans heresy as an indigenous western movement, p. 9-16.

25 The heretics of Orleans: Dicebant ergo deliramenta esse quicquid in veteri ac novo canone certis signis ac prodigiis veteribus testatoribus de trina et una deitate beata confirmat auctoritas (RODULFUs GLABER, III, 8, 27, p. 142); Syméon le Nouveau Théologien, Traité IX, 11, 40-43, [in:] IDem, Traites..., vol. II, p. 222; B. Krivochéine, op. cit., p. 279.

26 B. KRIVOchéIne, op. cit., p. 252.

27 M. Angold, Church and society in Byzantium under the Comneni, 1081-1261, Cambridge 1995, p. 473. The writings of Constantine Chrysomallus, who worked in the tradition of St. Symeon, were posthumously condemned by the Holy Synod of Constantinople in 1140 as heretical. See Christian Dualist Heresies..., p. 212-214 [n. 28: The posthumous trial of Constantine Chrysomallus for heresy (1140)]; P. MAGDaLINo, The empire of Manuel I Komnenos, 1143-1180, Cambridge 1993, p. 276. On the ways in which St. Symeon's teaching was misconstrued, H.J.M. Turner, St. Symeon the New Theologian and dualist heresies- comparisons and contrasts, SVTQ 32, 1988, p. 359-366. 
to misrepresent their position ${ }^{28}$. Both these factors may have helped to determine the Orleans trial.

Aréfast's account, though no doubt edited, gives some idea of the exchanges which took place between the canons and the bishops at the Orleans synod over a wide range of issues, but to judge from the Fleury evidence, the canons were condemned because they rejected the hierarchy and its sacraments, rather than because of their illuminist views. These were not necessarily heretical, although Aréfast, who was a layman without theological training, obviously thought that they were.

St. Symeon's ideas could have reached Orleans in one of two ways. The Western reformers of the tenth and early eleventh centuries held eastern traditions of spirituality in high regard, and treated its representatives with considerable respect when they came to western Europe ${ }^{29}$. That such influences were at work in the diocese of Orleans in the early eleventh century is clear from the Life of St. Gregory of Nicopolis, a Byzantine monk who lived in the church of St. Martin at Pithiviers for seven years. His biographer tells us that: He used to invite priests and monks and some religious lay-people [to eat with him on Sundays]... and fed them on bodily and also on spiritual food ${ }^{30}$. He must have been alive at the time when the canons of Orleans formed their religious group, but he clearly had no connection with it. His patron was the mother of bishop Odolricus of Orleans who was opposed to the canons and presided at their trial ${ }^{31}$. St. Gregory was only one among many eastern monks to be found in northern France at that time.

St. Symeon's teachings might equally well have been introduced by western people who had visited Constantinople or Bithynia; certainly there were many people from northern France who went on pilgrimage to the Holy Land by way of By-

${ }^{28}$ One accusation made against the canons which has no parallel in St. Symeon's teaching is belief in the eternity of the world. If they really held such an opinion it had probably arisen as a result of the revival of the study of Aristotelian logic in the northern French schools through the influence of Gerbert of Reims. St. Thomas Aquinas, working within that Aristotelian tradition, was later to admit that logic led to the conclusion that the material universe had always existed in dependence on God rather than that it had been created ex nihilo by him, which though not contrary to logic was only known through divine revelation: F.C. Copleston, Aquinas, Harmondsworth 1955, p. 136-143.

29 St. Romuald of Ravenna (d. 1027), who cannot be shown to have had any direct contact with eastern monks, nevertheless took the Lives of the desert fathers as his spiritual guide when formulating his own views on the life of perfection - Petri Damiani Vita beati Romualdi, 6, [in:] Fonti per la storia d'Italia, vol. XCIV, ed. G. TAвасCO, Roma 1957, p. 26; see also B. Hamilton, P.A. McNulty, Orientale lumen et magistra latinitas: Greek influences on Western monasticism (900-1000), [in:] Le millénaire du Mont Athos, 963-1963, Études et mélanges, Chevetogne 1963, vol. I, p. 181-216; R.L.WolfF, How the good news was brought from Byzantium to Angoulême; or the pursuit of a hare in an ox-cart, BMGS 4, 1979, p. 139-189.

${ }^{30}$ De S. Gregorio Episcopo Armeno Pitiveri in Gallia, col. XI, AASS, Martii 11, Antwerp 1668, (cetera: De S. Gregorio), p. 463.

${ }^{31}$ T. HEAD, Hagiography and the cult of saints. The diocese of Orleans, 800-1200, Cambridge 1990, p. 261-265, 272; Gregory's biographer is at pains to relate that the saint's bones, unlike those of the canons, proved to be fire-resistant when the church where he was buried burned down in 1044, thereby confirming his orthodoxy, De S. Gregorio, col. 11, p. 464. 
zantium at that time $\mathrm{e}^{32}$. There was therefore no lack of opportunity for the spiritual teachings of St. Symeon to become known at Orleans.

We cannot, of course, prove that they were, but we have pointed out the similarities between the two movements in the hope that this may open up discussion about the full range of possible religious contacts between Byzantium and the West in the time before the Crusades. This debate has hitherto been concerned chiefly with the possible influence of eastern dualist movements on the West, and that seems an unduly restrictive approach.

\begin{abstract}
The trial at Orleans in 1022 of a group of aristocratic clergy, who included the confessor of Queen Constance of France, and their followers on the charge of heresy is the most fully reported among the group of heresy trials which were conducted in the Western Church during the first half of the eleventh century. Although the alleged heretics of Orleans are usually considered a part of a wider pattern of Western religious dissent, the charges brought against them differ considerably from those levelled against the other groups brought to trial in that period.

The heterodox beliefs with which the canons of Orleans were charged bear a strong resemblance to the teachings of the Byzantine abbot, St. Symeon the New Theologian, who died in 1022. St. Symeon taught that it was possible for a Christian to experience the vision of God in this life if he or she received ascetic guidance from a spiritual director, who need not be a priest.

In the late tenth and early eleventh centuries a significant number of Orthodox monks visited northern Europe, including Orleans, and some of them settled there. It is therefore possible that the Canons of Orleans who were put on trial had been trained in the tradition of St. Symeon by one of those Orthodox monks who were familiar with it.

St. Symeon was part of the Hesychast tradition in the Byzantine Church. Even so, his emphasis on the supremacy of personal religious experience at the expense of the corporate worship of the institutional Church was strongly criticised by some of his contemporaries. A study of his writings shows that he was, in fact, completely Orthodox in faith and practice and that these criticisms were ill-judged. Nevertheless, if, as we have suggested, the Canons of Orleans had tried to live in accordance with his teachings, the hostile reactions of the Western hierarchy would be comprehensible. For there was no tradition of Hesychasm in the spirituality of the Western Church, and the fact that the dissidents at Orleans saw little value in observing the rituals of the established Church would have alarmed conventional churchmen.
\end{abstract}

Bernard and Janet Hamilton

7 Lenton Avenue

The Park

Nottingham NG7 1 DX

England, UK

32 J. Ebersolt, Orient et Occident. Recherches sur les influences byzantines et orientales en France avant et pendant les croisades, ${ }^{2}$ Paris 1954, p. 49-70. 